\title{
Computational Analysis of Performance Limiting Factors for the New Solid Oxide Iron-air Redox Battery Operated at $550^{\circ} \mathrm{C}$
}

\author{
Xinfang Jin ${ }^{1}$, Xuan Zhao ${ }^{1}$, Cuijuan Zhang ${ }^{1}$, Ralph E. White ${ }^{2}$ and Kevin Huang ${ }^{1}$ * \\ ${ }^{1}$ Department of Mechanical Engineering, University of South Carolina, Columbia, SC 29208, \\ USA \\ ${ }^{2}$ Department of Chemical Engineering, University of South Carolina, Columbia, SC 29208, USA \\ *Corresponding Author. Tel: 1-803-777-0204, Fax: 1-803-777-0106 \\ Email: Huang46@,cec.sc.edu
}

\begin{abstract}
In the present study, the effects of discharge and charge current densities, depth-of-discharge, initial porosity of Redox Cycle Unit (RCU), distance between Reversible Solid Oxide Fuel Cell (RSOFC) and $\mathrm{RCU}$, and kinetic rate constant for the $\mathrm{Fe}_{3} \mathrm{O}_{4}$-reduction reaction on the electrochemical performance of a Solid Oxide Iron-Air Redox Battery (SOIARB) operated at $550^{\circ} \mathrm{C}$ have been systematically investigated by a newly developed high-fidelity multi-physics model. The results show explicitly that the battery performance is kinetically limited by the $\mathrm{Fe}_{3} \mathrm{O}_{4}$-reduction during the charge cycle. The diffusion of Oxygen Shuttle Gas (OSG), i.e. $\mathrm{H}_{2}$ $\mathrm{H}_{2} \mathrm{O}$, through the RCU pores and the gap between RSOFC and RCU is sufficiently fast. The most influential parameters on the performance are found to be the charge current density, depthof-discharge and rate of $\mathrm{Fe}_{3} \mathrm{O}_{4}$ reduction. Strategies for design and operation of the SOIARB are subsequently developed with an aim to achieve a balanced energy capacity and cycle efficiency.
\end{abstract}

Keywords: energy storage; solid oxide fuel cell; battery; modeling; $\mathrm{Fe}_{3} \mathrm{O}_{4}$ reduction 


\section{Introduction}

Large-scale and cost effective stationary energy storage is a key to successful implementation of renewable energy into the existing power grid. Sodium-sulfur and redox flow batteries have been traditionally regarded as the promising stationary energy storage technologies for harnessing solar and winds energy. However, these two technologies have not been fully implemented at commercial scale due to obstacles in cost and reliability. Recently, we demonstrated a new dual-functional hybrid fuelcell/battery system capable of producing power and storing energy with advanced features: solid oxide metal-air redox battery or SOMARB. Since the first laboratory demonstration in $2011^{1}$, significant experimental progress on SOMARB has been made in the areas of the material properties ${ }^{2,3}$, new metal-air chemistries ${ }^{4-9}$ and the system design ${ }^{10-15}$.

Compared to the productive experimental investigations, the mathematical modeling of the multi-physicochemical processes occurring inside the battery remains underdeveloped. For example, Ohmoti et al ${ }^{16}$ and Guo et al ${ }^{17}$ reported multiphysics models with ignored redox reaction kinetics and simplified battery configurations. To advance the development of modeling in this area, we recently developed a high-fidelity multiphysics model for the new solid-oxide iron-air redox battery (SOIARB) ${ }^{18,19}$. The model combines fundamental theories of mass transport, charge transfer and chemical redox kinetics, and can reasonably predict the electrochemical behavior of a SOIARB. One of the distinctive features of the new model is the application of Johnson-Mehl-Avrami-Kolmogorov $(\mathrm{JMAK})^{24-27}$ and Shrinking Core ${ }^{28-29}$ theories to simulate the oxidation of Fe and reduction of $\mathrm{Fe}_{3} \mathrm{O}_{4}$ kinetics occurring inside the redox cycle unit (RCU), respectively. Furthermore, the parameters used in the model were directly derived from the Voltage-Current (V-I) 
curves and the charge/discharge characteristics obtained from experiments ${ }^{12}$, ensuring a high-fidelity analysis and prediction.

In the present study, we apply the developed computational model to systematically analyze the effects of the most important design and operational parameters on the SOIARB's performance, based on which a set of optimization strategies are outlined for future commercial development of the new SOIARB technology. The analysis presented in this work is on a SOIARB operated at $550^{\circ} \mathrm{C}$ and has not been reported previously. The selection of $550^{\circ} \mathrm{C}$ in this study as the operating temperature is based on the consideration of available experimental data and the desire for intermediate-temperature operation to achieve long lifetime and high reliability.

\section{The SOIARB technology}

The solid oxide iron-air redox battery or SOIARB is composed of a reversible solid oxide fuel cell (RSOFC), an iron-iron oxide redox cycle unit (RCU) and an Oxygen Shuttle Gas $\left(\mathrm{H}_{2}-\mathrm{H}_{2} \mathrm{O}\right)$ chamber in between, as shown in Fig. $1 \mathrm{a}^{18}$. The operating temperature of interest for this study is $550^{\circ} \mathrm{C}$, at which $\mathrm{Fe} / \mathrm{Fe}_{3} \mathrm{O}_{4}$ is the prevalent redox couple in the RCU. The $2 \mathrm{D}$ axis-symmetric model is shown in Fig. $1 \mathrm{~b}^{18}$. The details regarding the SOFC materials could be found in our recent publications ${ }^{24,25}$.

The RSOFC utilizes its SOFC and SOEC modes to realize electrical discharge and charge, respectively. During discharge, the RSOFC electrochemically consumes $\mathrm{O}_{2}$ and $\mathrm{H}_{2}$ to produce $\mathrm{H}_{2} \mathrm{O}$ and electricity, while $\mathrm{Fe}$ is being oxidized by $\mathrm{H}_{2} \mathrm{O}$ produced to form $\mathrm{Fe}_{3} \mathrm{O}_{4}$ and $\mathrm{H}_{2}$ to sustain the electrochemical oxidation. During the charge cycle, RSOFC electrochemically splits $\mathrm{H}_{2} \mathrm{O}$ into $\mathrm{H}_{2}$ with external electrical energy supply, while $\mathrm{Fe}_{3} \mathrm{O}_{4}$ 
is being reduced back to $\mathrm{Fe}$ with $\mathrm{H}_{2}$ produced and to form $\mathrm{H}_{2} \mathrm{O}$ to sustain the electrolysis process. We assume that in RCU, forward reactions occurs for discharge, then backward reactions happen for charge. The electrochemical and chemical reactions occurring within RSOFC and RCU are:

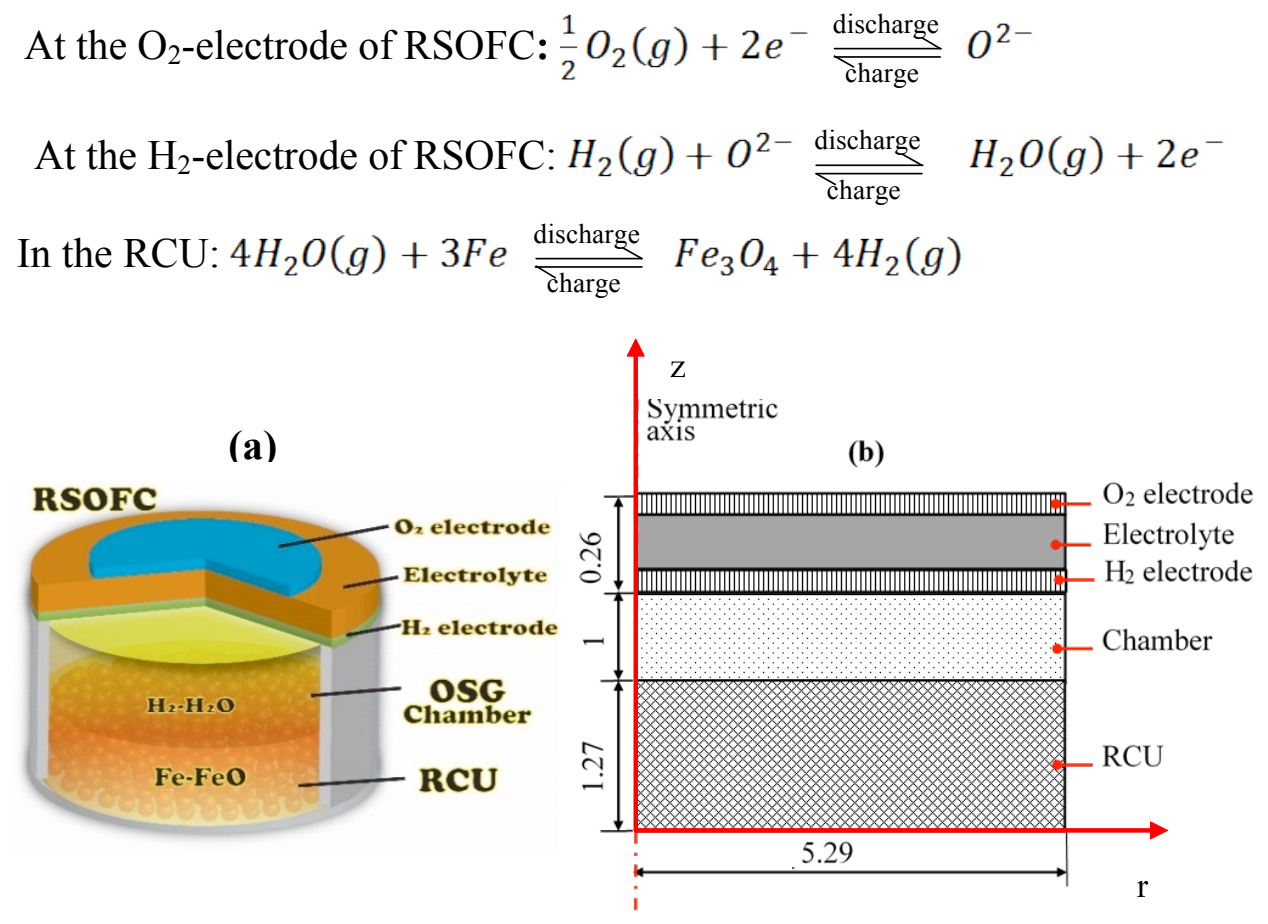

Fig.1 (a) A schematic illustration of the SOIARB configuration; (b) Finite Element Method (FEM) model of SOIARB (unit: $\mathrm{mm})^{18}$.

\section{The multiphysics model}

The multi-physics processes occurring in SOIARB includes: electron/oxygen-ion transport in the RSOFC; electrochemical reactions in RSOFC electrodes; gas diffusion in porous electrodes of RSOFC, open gas chamber and porous RCU bed; redox reactions in RCU bed. The governing equations are summarized in Table 1. The meanings of the symbols used here are listed in the Nomenclature. The convective mass transfer of concentrated species is neglected due to the fact that it is a closed stationary system.

Table 1 Governing equations used in the model 


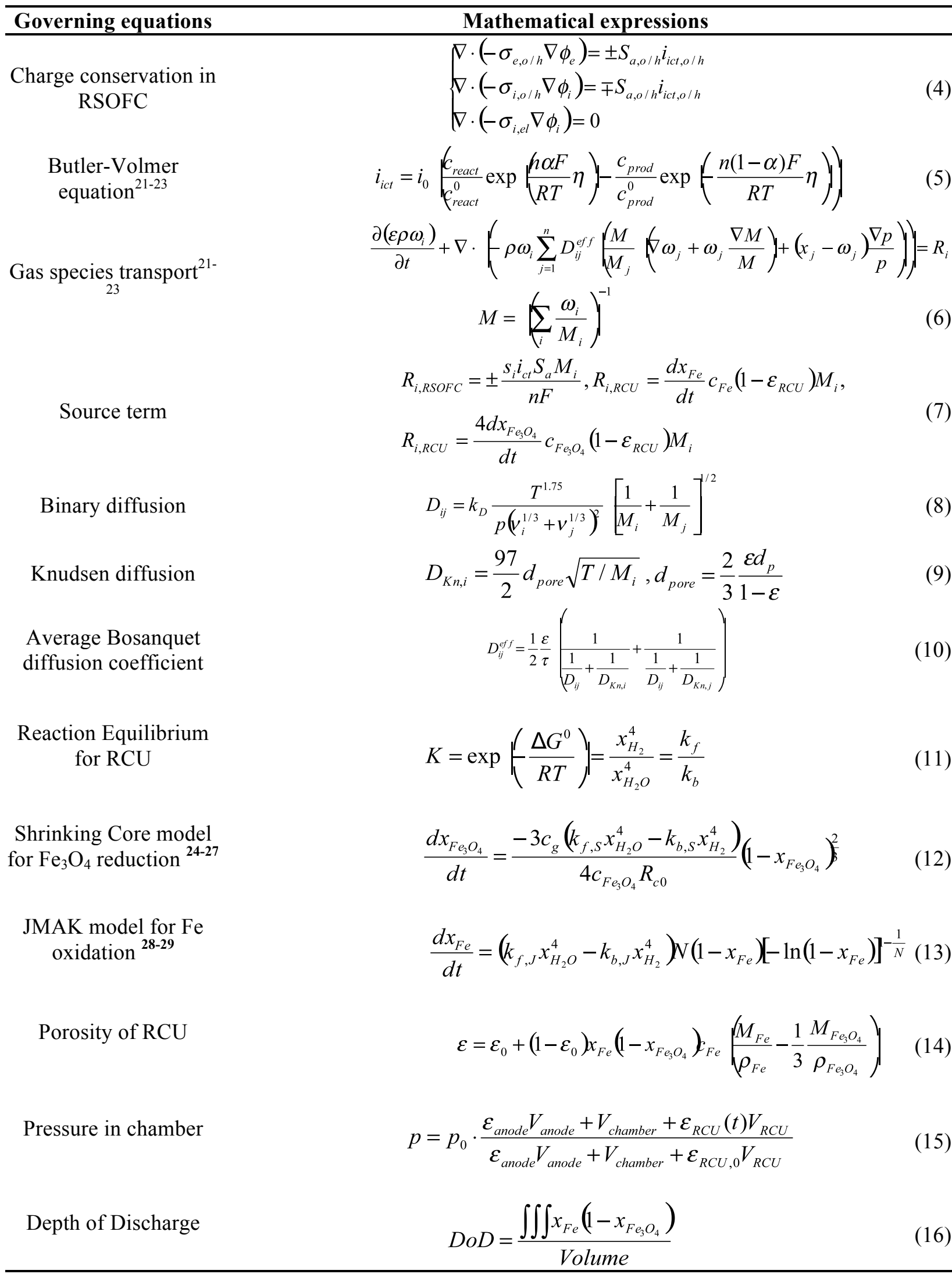


Specific Energy

$$
S E=\int_{t_{1}}^{t_{2}} \frac{V \times J \times A}{3600 \times D o D \times m_{F e, 0}}
$$

Round Trip Efficiency

$$
R T E=\frac{S E_{d}}{S E_{c}}
$$

\subsection{The boundary/initial conditions}

Boundary conditions are given in Table 2. Based on the experimental information, the initial gas mole fraction ratio in the chamber was taken as $\mathrm{H}_{2}: \mathrm{H}_{2} \mathrm{O}=0.97: 0.03$. The initial condition for the reacted mole fraction of $\mathrm{Fe}$ is set to $x_{F e .0}=10^{-5}$ (a very small number for calculation purpose).

\begin{tabular}{|c|c|c|c|}
\hline Boundary & $\begin{array}{c}\text { Electronic } \\
\text { potential }\end{array}$ & Ionic potential & Stefan-Maxwell diffusion \\
\hline Dependent Variable & $\phi_{\mathrm{e}}$ & $\phi_{\mathrm{i}}$ & $\omega_{j}$ \\
\hline Air channel/ $\mathbf{O}_{2}$ electrode & $-\underline{\mathbf{n}} \cdot \nabla \phi_{e}=J_{c / d}$ & $-\underline{\mathbf{n}} \cdot \nabla \phi_{i}=0$ & $\mathrm{O}_{2}: \mathrm{N}_{2}: \mathrm{H}_{2} \mathrm{O}=0.21: 0.76: 0.03$ \\
\hline $\begin{array}{c}\mathrm{O}_{2} \text {-electrode/electrolyte } \\
\text { interface }\end{array}$ & $-\underline{\mathbf{n}} \cdot \nabla \phi_{e}=0$ & Continuity & $-\underline{\mathbf{n}} \cdot \underline{N_{i}}=0$ \\
\hline $\begin{array}{c}\text { electrolyte } / \mathrm{H}_{2} \text {-electrode } \\
\text { interface }\end{array}$ & $-\underline{\mathbf{n}} \cdot \nabla \phi_{e}=0$ & Continuity & $-\underline{\mathbf{n}} \cdot \underline{N_{i}}=0$ \\
\hline $\mathrm{H}_{2}$ electrode/Chamber & $0 \mathrm{~V}$ & $-\underline{\mathbf{n}} \cdot \nabla \phi_{i}=0$ & Continuity \\
\hline Chamber/RCU & $\mathrm{N} / \mathrm{A}$ & N/A & Continuity \\
\hline Other surfaces & $-\underline{\mathbf{n}} \cdot \nabla \phi_{e}=0$ & $-\underline{\mathbf{n}} \cdot \nabla \phi_{i}=0$ & $-\underline{\mathbf{n}} \cdot \underline{N_{i}}=0$ \\
\hline
\end{tabular}

Table 2 Boundary conditions used in the model

Note; $\underline{\boldsymbol{N}}_{\boldsymbol{i}}=-\rho \omega_{i} \sum_{j} D_{i j}^{e f f} \underline{\mathbf{d}}_{j}, \underline{\mathbf{d}}_{j}=\left(\frac{M}{M_{j}}\left(\nabla \omega_{j}+\omega_{j} \frac{\nabla M}{M}\right)+\left(x_{j}-\omega_{j}\right) \frac{\nabla p}{p}\right)$.

\subsection{The Computation and validation}

The electronic potential $\phi_{e}$ and ionic potential $\phi_{i}$, mass fraction of gas species, $\omega_{j}$, the reacted fraction ratio $x_{F e} / x_{F \rho_{n} \cap}$. are computed as a function of time by combining eqs. (4), (5), (6), (12) and (13) with the boundary/initial conditions aforementioned. 
The computation was performed with a commercial software package known as COMSOL Multiphysics 4.3 using a workstation equipped with an Intel Core i7-4700MQ processor @ $2.4 \mathrm{GHz}$ and $2.39 \mathrm{GHz}$ and 16GB of RAM. The computational domain was discretized by swept mesh and refined until a converged solution was reached. The Direct Solver was applied to solve the transient problem. The modules applied in the model include Electric Currents module, Transport of Concentrated Species module, and General form of Partial Differential Equations.

To ensure high fidelity of the model, the exchange current density of RSOFC was extracted from an experimental V-I curve obtained from our previous study ${ }^{20}$; the results are shown in Fig. $2^{18}$. Meanwhile, the reaction rate constants in JMAK and Shrinking Core model were obtained from an experimental Discharge/Charge curve of the battery as a function of time; the results are shown in Fig. $3^{12,18}$. The physical and chemical parameters obtained are listed in Table 3.

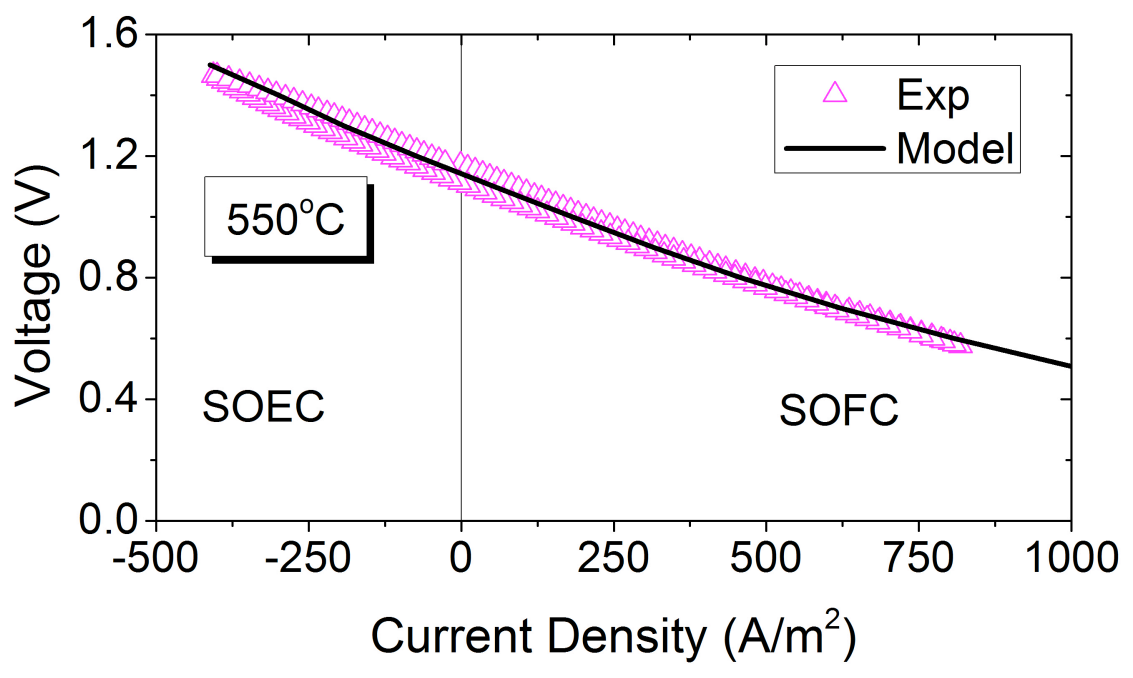

Fig. 2 Validation of V-I curve under $550^{\circ} \mathrm{C}^{18}$. 


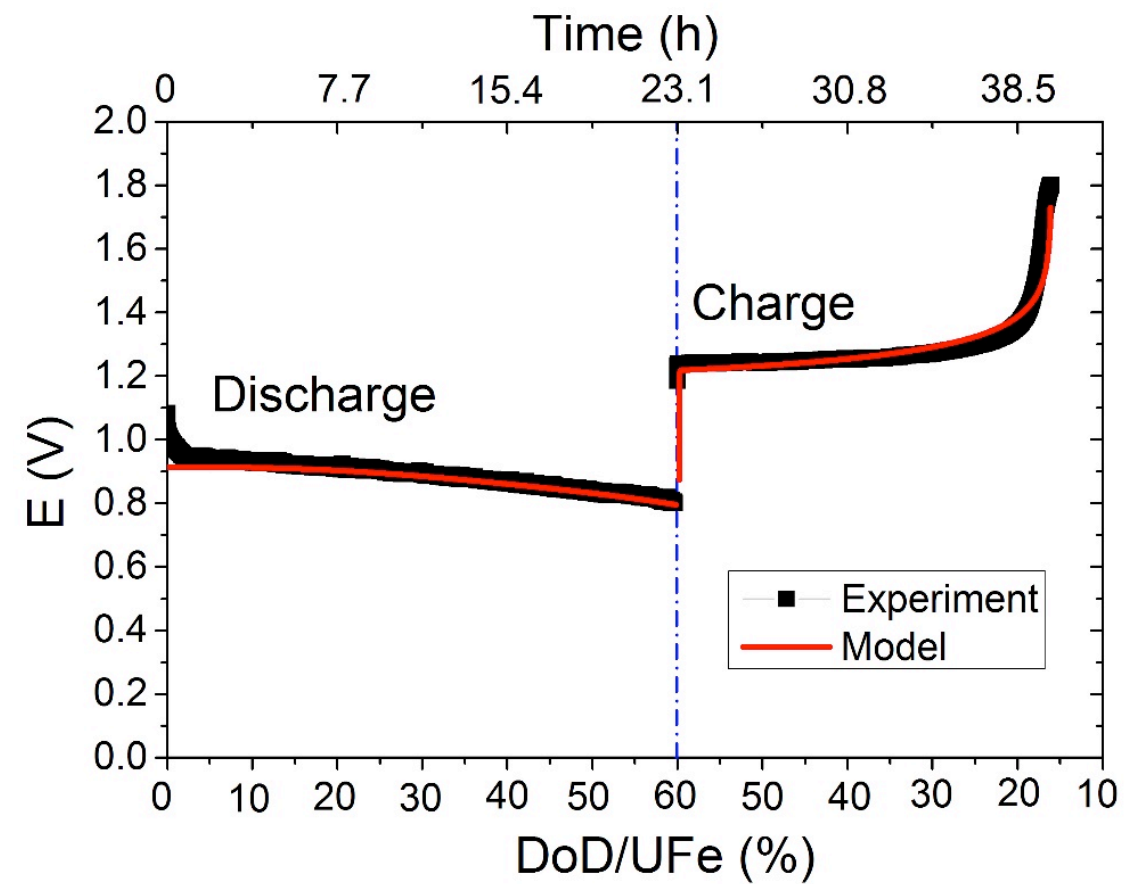

Fig. 3 Validation of E vs DoD (UFe: Fe utilization) curve $^{18}$.

Table 3 Parameters used in the model

\begin{tabular}{lc}
\hline Parameters & Values \\
\hline Atmospheric pressure, $\mathrm{p}_{0}$ & $1[\mathrm{~atm}]$ \\
Avrami exponent of JMAK, $\mathrm{N}$ & 0.28 \\
Charging/Discharging current density, $\mathrm{J}_{\mathrm{c}} / \mathrm{J}_{\mathrm{d}}$ & $100\left[\mathrm{~A} / \mathrm{m}^{2}\right]$ \\
Distance between RSOFC and RCU, $\mathrm{d}$ & $1 \mathrm{~mm}$ \\
Diameter of spherical particle, Anode/Cathode, $\mathrm{d}_{\mathrm{p}}$ & $0.35[\mu \mathrm{m}]$ \\
Electronic conductivity, $\sigma_{\mathrm{e}}$ & $2 \times 10^{6}[\mathrm{~S} / \mathrm{m}]$ \\
Exchange current density for SOFC, & $75 / 15\left[\mathrm{~A} / \mathrm{m}^{2}\right]$ \\
Anode/Cathode $\mathrm{i}_{0}^{*}$ & $11.25 / 15\left[\mathrm{~A} / \mathrm{m}^{2}\right]$ \\
Exchange current density for SOEC, Anode/Cathode & \\
$\mathrm{i}_{0} *$ & 186 \\
Equilibrium reaction constant, $\mathrm{K}$ & $1.15[\mathrm{~S} / \mathrm{m}]$ \\
Ionic conductivity, $\sigma_{\mathrm{i}, \mathrm{el}}{ }^{*}$ & 0.7 \\
Initial porosity of $\mathrm{RCU}, \varepsilon_{0}$ & 0.97 \\
Inlet mole fraction of $\mathrm{H}_{2} \mathrm{X}_{\mathrm{ref}, \mathrm{H} 2}$ & 0.21 \\
Inlet mole fraction of $\mathrm{O}_{2} \mathrm{X}_{\mathrm{ref}, \mathrm{O} 2}$ & $6 \times 10^{-6}$ \\
Kinetic volume of $\mathrm{H}_{2}, \mathrm{vh}_{2}$ & $16.6 \times 10^{-6}$ \\
Kinetic volume of $\mathrm{O}_{2}, \mathrm{vo}_{2}$ & \\
\hline
\end{tabular}




\begin{tabular}{lc}
\hline Kinetic volume of $\mathrm{N}_{2}, \mathrm{vn}_{2}$ & $17.9 \times 10^{-6}$ \\
Kinetic volume of $\mathrm{H}_{2} \mathrm{O}, \mathrm{vh}_{2} \mathrm{O}$ & $12.7 \times 10^{-6}$ \\
Loading of Iron, $\mathrm{m}_{\mathrm{Fe}}$ & $0.26[\mathrm{~g}]$ \\
Number of electrons, $\mathrm{n}$ & 2 \\
Porosity, Anode/Cathode $\varepsilon$ & $0.4 / 0.3$ \\
Permeability of electrodes, $\kappa$ & $10^{-13}\left[\mathrm{~m}^{2}\right]$ \\
Radius of $\mathrm{Fe}_{3} \mathrm{O}_{4}$ particle, $\mathrm{R}_{\mathrm{c} 0}$ & $1[\mu \mathrm{m}]$ \\
Reference diffusivity, $\mathrm{k}_{\mathrm{D}}$ & $3.16 \times 10^{-8}\left[\mathrm{~m}^{2} / \mathrm{s}\right]$ \\
Reaction rate constant of JMAK, $\mathrm{k}_{\mathrm{f}, \mathrm{J}} / \mathrm{k}_{\mathrm{b}, \mathrm{J}}{ }^{*}$ & $10 \times 4.7 \times 10^{-5} / 0.0538 \times 4.7 \times 10^{-5}[1 / \mathrm{s}]$ \\
Reaction rate constant of shrinking core model, & $10 \times 3.83 \times 10^{-7} / 0.0538 \times 3.83 \times 10^{-7}[\mathrm{~m} / \mathrm{s}]$ \\
$\mathrm{k}_{\mathrm{f}, \mathrm{S}} / \mathrm{k}_{\mathrm{b}, \mathrm{s}} *$ & $\left(1-\varepsilon_{\mathrm{a} / \mathrm{c}}\right) \times 1.43 \times 10^{5}[1 / \mathrm{m}]$ \\
Specific surface area, Anode/Cathode $\mathrm{S}_{\mathrm{a}}{ }^{*}$ & $550\left[{ }^{\circ} \mathrm{C}\right]$ \\
Temperature, $\mathrm{T}_{0}$ & 3 \\
Tortuosity, Anode/Cathode $\tau^{*}$ & 0.25 \\
Transfer coefficient, $\alpha$ & $4 \times 10^{-5}[\mathrm{~Pa} \cdot \mathrm{s}]$ \\
Viscosity of air, $\mu$ & \\
\hline Note: The parameters with $*$ are adjusted in order to validate the model with the experimental results.
\end{tabular}

\section{Parametric study on the performance limiting factors}

The key parameters of the SOIARB investigated in this study include discharge/charge current density $\left(\mathrm{J}_{\mathrm{d}} / \mathrm{J}_{\mathrm{c}}\right)$, Depth-of-Discharge (DoD), distance between the RSOFC and $\mathrm{RCU}(\mathrm{d})$, initial porosity of the $\mathrm{RCU}\left(\varepsilon_{0}\right)$ and the kinetic rate constant $\left(\mathrm{k}_{\mathrm{b}, \mathrm{S}}\right)$ of $\mathrm{Fe}_{3} \mathrm{O}_{4^{-}}$ reduction reaction. All of the analysis was conducted under an isothermal condition $\left(\mathrm{T}=550^{\circ} \mathrm{C}\right)$, from which performance optimization strategies were developed for the future engineering design and practical operation of this SOIARB. The cut-off voltage for the charge cycle was set as $1.8 \mathrm{~V}$ in the following discussion.

\subsection{The effect of current density}


The current density $\left(\mathrm{J}=\mathrm{J}_{\mathrm{c}}=\mathrm{J}_{\mathrm{d}}\right)$ applied across the RSOFC dictates the dynamic interaction between the RSOFC and the RCU. While the $\mathrm{J}$ of the RSOFC can be galvanically controlled, the magnitude of a sustainable cell voltage associated with $\mathrm{J}$ depends upon the ability of the RCU to produce sufficient $\mathrm{H}_{2}$ and $\mathrm{H}_{2} \mathrm{O}$ for the discharge and charge cycles, respectively. This is shown in Fig.4, where J-profiles of the RSOFC are depicted as a function of the cycle time. It is taken as positive for discharge cycle, and negative for charge cycle. With $\mathrm{J}=100 \mathrm{~A} / \mathrm{m}^{2}$, the discharge cycle lasted 23 hours for a DoD (or Fe utilization as defined below) of 0.6 , during which Fe in the RCU was being oxidized to produce $\mathrm{H}_{2}$ to support the electrochemical oxidation of $\mathrm{H}_{2}$ at the $\mathrm{H}_{2}$-electrode in the RSOFC.

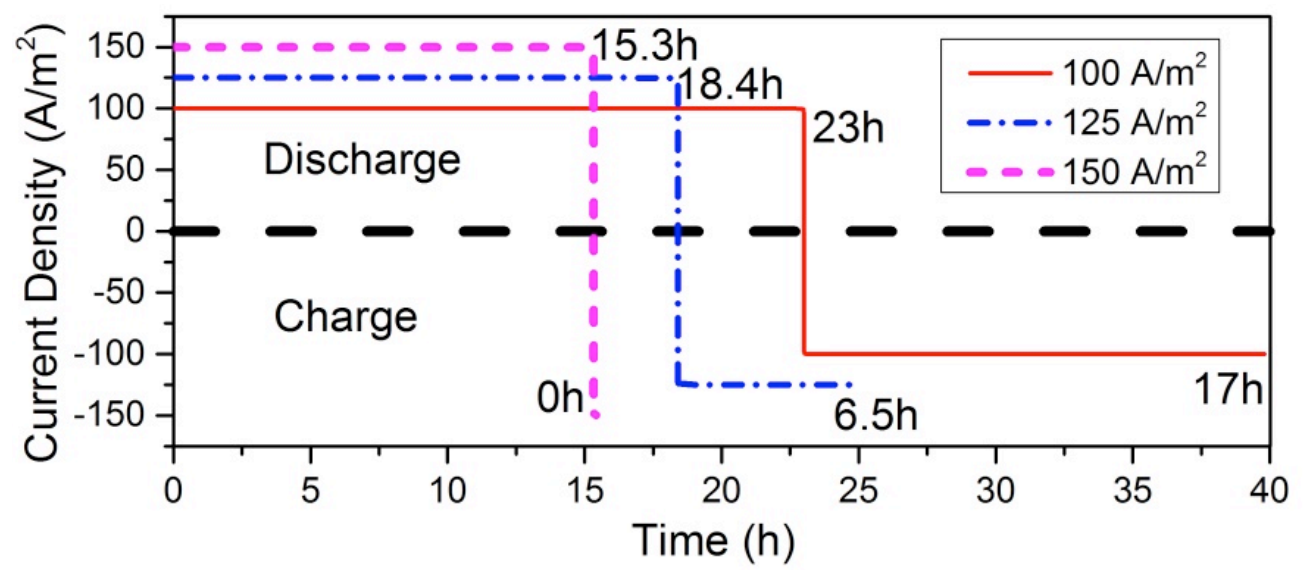

Fig.4 Current density at the RSOFC with $\mathrm{DoD}=0.6\left(\varepsilon_{0}=0.7 ; \mathrm{d}=1 \mathrm{~mm}\right)$ effect on discharge and charge time.

During the charge cycle when $\mathrm{Fe}_{3} \mathrm{O}_{4}$ in the RCU is being reduced by $\mathrm{H}_{2}$ to produce $\mathrm{H}_{2} \mathrm{O}$ to sustain the electrochemical reduction of $\mathrm{H}_{2} \mathrm{O}$ at the $\mathrm{H}_{2}$-electrode in the $\mathrm{RSOFC}$, only 17 hours can be maintained before the cut-off voltage at 1.8 volt occurs, reflecting $16 \%$ unconverted $\mathrm{Fe}_{3} \mathrm{O}_{4}$ compared to the initial condition in the $\mathrm{RCU}$ and hence a degree of 
irreversibility. At higher current density $\mathrm{J}=\mathrm{J}_{\mathrm{c}}=\mathrm{J}_{\mathrm{d}}=120 \mathrm{~A} / \mathrm{m}^{2}$, the irreversibility becomes even worse; the charge cycle lasted only for 6.5 hours, corresponding to $39 \%$ unconverted $\mathrm{Fe}_{3} \mathrm{O}_{4}$ from the original; at $\mathrm{J}=\mathrm{J}_{\mathrm{c}}=\mathrm{J}_{\mathrm{d}}=150 \mathrm{~A} / \mathrm{m}^{2}$, it becomes totally impossible to recharge the battery.

The Depth of Discharge (DoD) of RCU is equivalent to the Fe utilization in this study, which was calculated by integrating the rate of the redox reaction in the whole domain over time, as shown in Table1, equation (16). It is displayed in Fig.5 as a function of the cycle time; it further illustrates the difficulty of recharging the battery at higher J. For a $\mathrm{DoD}=0.6$, the reversibility (or Round-Trip-Efficiency, RTE) is $\sim 73 \%(=17 \mathrm{~h} / 23 \mathrm{~h}$ ) at $\mathrm{J}=\mathrm{J}_{\mathrm{c}}=\mathrm{J}_{\mathrm{d}}=100 \mathrm{~A} / \mathrm{m}^{2}$, but it drops to $33 \%(6.5 \mathrm{~h} / 18.4 \mathrm{~h})$ for $\mathrm{J}=\mathrm{J}_{\mathrm{c}}=\mathrm{J}_{\mathrm{d}}=120 \mathrm{~A} / \mathrm{m}^{2}$ and becomes completely irreversible at $\mathrm{J}=\mathrm{J}_{\mathrm{c}}=\mathrm{J}_{\mathrm{d}}=150 \mathrm{~A} / \mathrm{m}^{2}$.

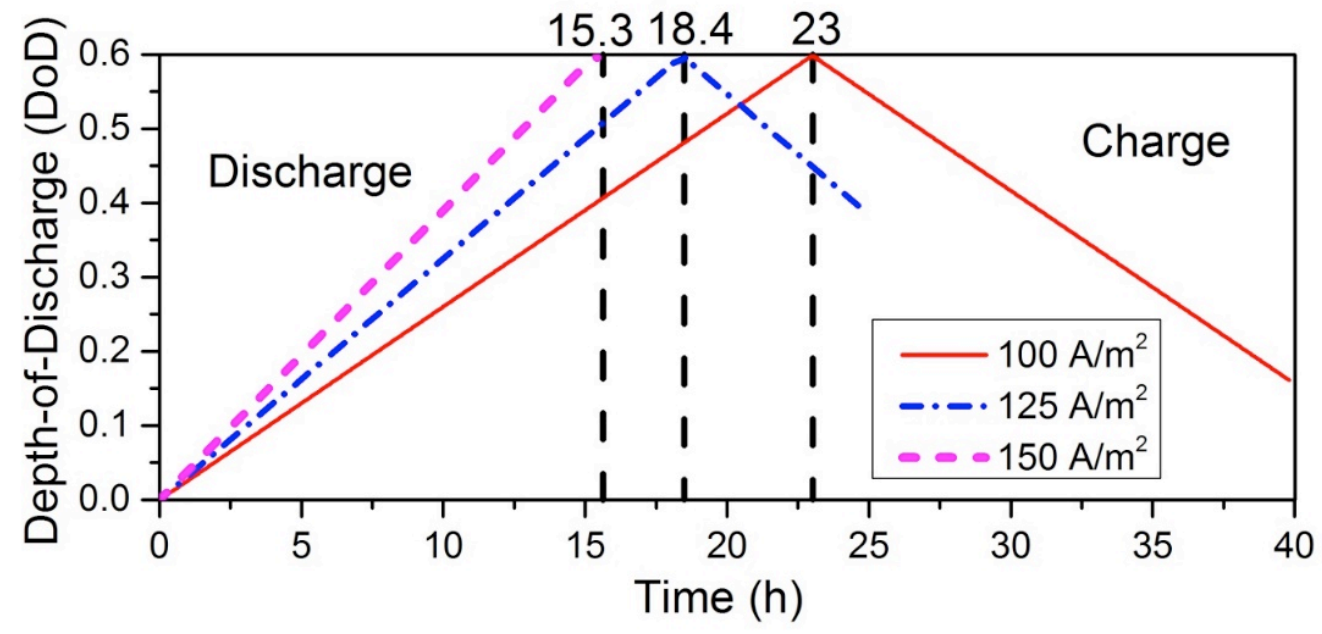

Fig.5 Volume averaged DoD as a function of cycle time. $\left(\varepsilon_{0}=0.7 ; \mathrm{d}=1 \mathrm{~mm}\right)$ 
The discharge profiles of the cell voltage are shown in the bottom half of Fig.6 as reasonable electrochemical behavior of a battery. The initial instant drop from $1.14 \mathrm{~V}$ (the Nernst potential at $\mathrm{H}_{2} / \mathrm{H}_{2} \mathrm{O}=0.97 / 0.03$ of the initial gas composition prior to cycling) to a stabilized current-dependent voltage reflects the chemical equilibrium established between the oxygen shuttle gas (OSG) and RCU. At lower DoDs, the voltage remains relatively flat, implying a good match between $\mathrm{J}$ and rate of $\mathrm{H}_{2}$ production $\left(\mathrm{r}_{\mathrm{H} 2}\right)$, whereas at higher DoDs the voltage begins to bend-over, implying a lowered $\mathrm{H}_{2} / \mathrm{H}_{2} \mathrm{O}$ ratio (compared to the equilibrium ratio of $0.79 / 0.21$ with Nernst potential of $1.067 \mathrm{~V}$ ) in the OSG caused by unmatched $\mathrm{r}_{\mathrm{H} 2}$ to the demanding $\mathrm{J}$.

The charge profiles under different $J$ shown in the top half of Fig. 6 are more revealing. The chargeable time of the battery before reaching a cut-off voltage of $1.8 \mathrm{~V}$ is significantly reduced with increasing $\mathrm{J}$, indicating the loss of reversibility; the latter is consistent with the results shown in Fig.4 and 5. Comparison of both the discharge and charge cycle profiles strongly suggests that the charge cycle or the reduction kinetics of $\mathrm{Fe}_{3} \mathrm{O}_{4}$ is the performance limiting step for the battery.

Correspondingly, the profiles of $\mathrm{H}_{2}$ mole fraction in the RCU as a function of DoD under different $\mathrm{J}$ are shown in Fig.7a; it further supports the observation in Fig.6.

During the discharge cycle, the $\mathrm{H}_{2}$ mole fraction can only maintain the equilibrium concentration of 0.79 at $\mathrm{DoD} \leq 0.1$, above which a decrease with $\mathrm{DoD}$ is observed. During the charge cycle, only a small fraction of $\mathrm{H}_{2} \mathrm{O}$ (complementary to $\mathrm{H}_{2}$ shown in Fig.7a) is present in the OSG to support the electrochemical reduction and becomes completely depleted at $\mathrm{J}=\mathrm{J}_{\mathrm{c}}=\mathrm{J}_{\mathrm{d}}=150 \mathrm{~A} / \mathrm{m}^{2}$. The inability for the RCU to produce $\mathrm{H}_{2} \mathrm{O}$ fast enough to 
match the electrolysis $J$ is the root cause of the poor charging performance. Therefore, the reduction kinetics of $\mathrm{Fe}_{3} \mathrm{O}_{4}$ needs to be further enhanced in the future materials research in order to improve the overall performance of the new SOIARB.

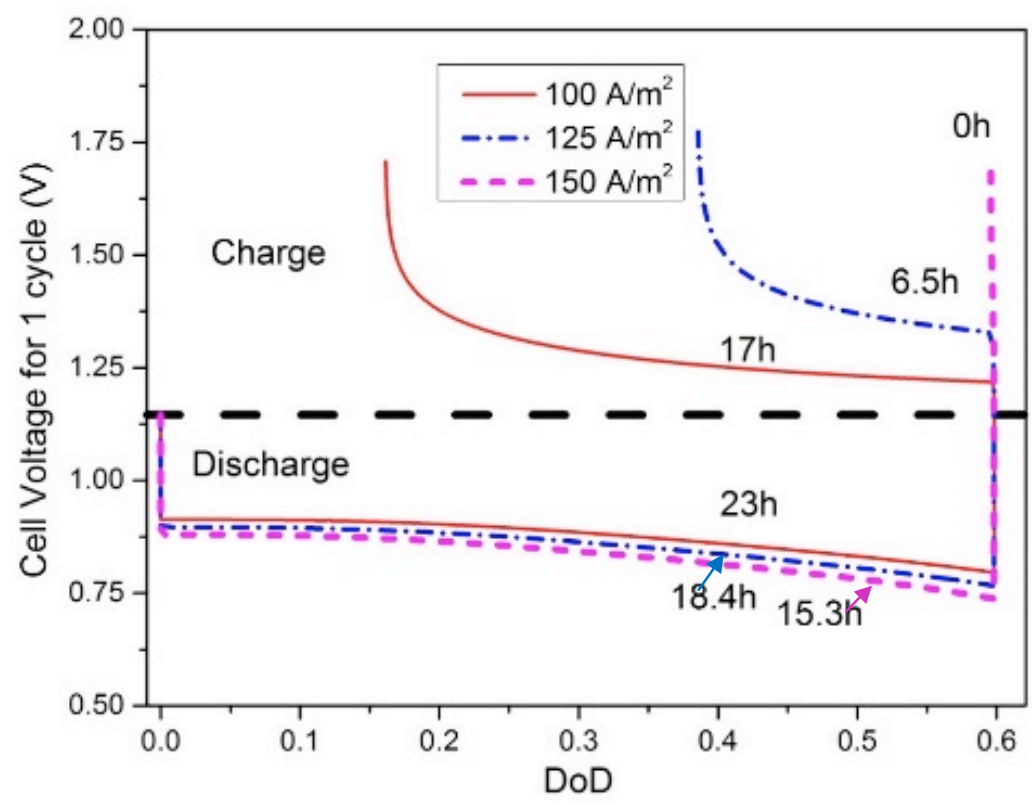

Fig.6 Profiles of cell voltage of the RSOFC during a discharge/charge cycle as a function of DoD under different current densities. $\left(\varepsilon_{0}=0.7 ; \mathrm{d}=1 \mathrm{~mm}\right)$ (Heavy dashed line is the Nernst potential, 1.14V.)

Since the Nernst potential is directly related to the ratio of $\mathrm{H}_{2} / \mathrm{H}_{2} \mathrm{O}$ in the OSG, its profiles should resemble Fig.7a. Indeed, Nernst potential profiles of Fig. $7 \mathrm{~b}$ confirm it in both shape and trending. 

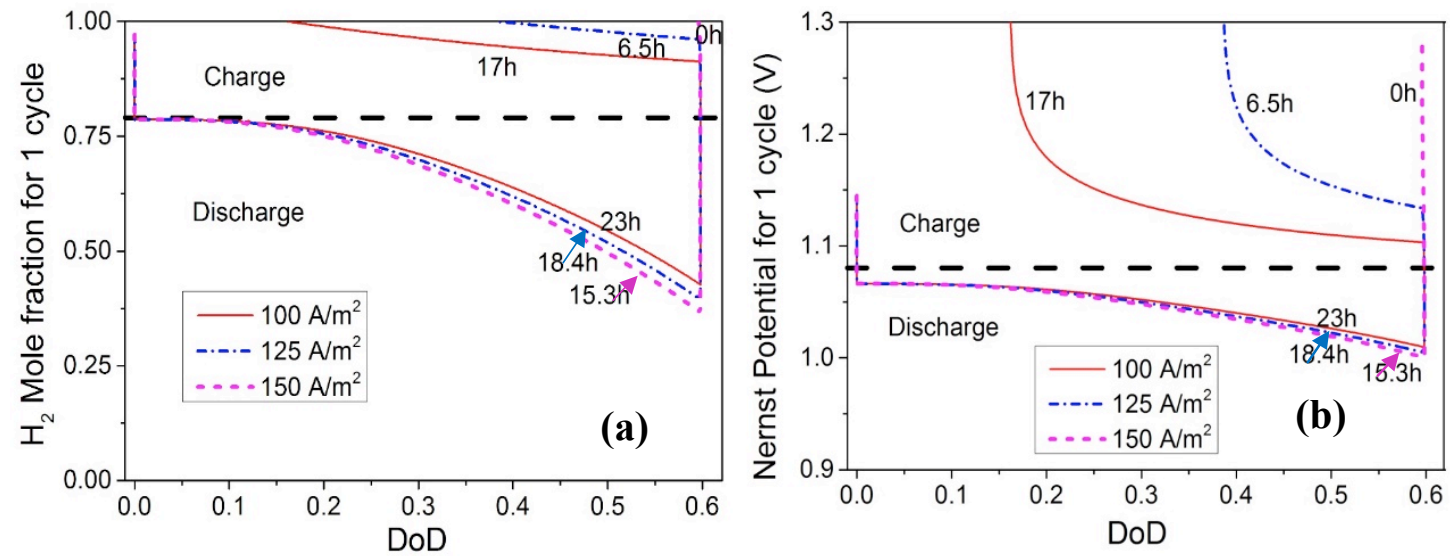

Fig.7 (a) Profiles of $\mathrm{H}_{2}$ mole fraction in the RCU; (b) Nernst Potential of RSOFC during a discharge/charge cycle as a function of DoD under different $J .\left(\varepsilon_{0}=0.7 ; \mathrm{d}=1 \mathrm{~mm}\right)$

In summary, the charge cycle is identified as the performance-limiting step of the SOIARB. The root cause for the difficulty to recharge the battery is two folded: 1) the equilibrium composition of the $\mathrm{OSG}$, i.e. $\mathrm{H}_{2} / \mathrm{H}_{2} \mathrm{O}=79 / 21$ at $550^{\circ} \mathrm{C}$, is less favorable to the $\mathrm{Fe}_{3} \mathrm{O}_{4}$-reduction of the charge cycle; 2) the intrinsic kinetics of $\mathrm{Fe}_{3} \mathrm{O}_{4}$-reduction is more sluggish than Fe-oxidation, which has also been implied by the upward charging curve of a $550^{\circ} \mathrm{C}-\mathrm{SOIARB}{ }^{10}$. Therefore, improving the kinetics of $\mathrm{Fe}_{3} \mathrm{O}_{4}$ reduction during the charge cycle is an important task to a commercial development of the SOIARB technology.

\subsection{The effect of initial porosity in RCU}

Since the molar volumes of $\mathrm{Fe}$ and $\mathrm{Fe}_{3} \mathrm{O}_{4}$ are different, the porosity in $\mathrm{RCU}$ will vary with DoD, i.e. the porosity decreases with DoD during the discharge cycle and reversibly increases with DoD during the charge cycle, e.g., the porosity is lowered to 0.475 from the initial $\varepsilon_{\mathrm{o}}=0.70$ after exposure to $\mathrm{J}=\mathrm{J}_{\mathrm{c}}=\mathrm{J}_{\mathrm{d}}=100 \mathrm{~A} / \mathrm{m}^{2}$ and $\mathrm{DoD}=0.6$. The porosity change in RCU during the discharge cycle could affect the mass transport of $\mathrm{H}_{2}$ and $\mathrm{H}_{2} \mathrm{O}$, thus the performance of the battery. 
The effect of $\varepsilon_{\mathrm{o}}$ in RCU on battery's performance is shown in Fig.8, where the profiles of cell voltage as a function of DoD during a discharge/charge cycle under $J=J_{c}=J_{d}=100 A / m^{2}$ are depicted for different $\varepsilon_{\mathrm{o}}$. It is evident that $\varepsilon_{\mathrm{o}}$ in the range of 0.45 to 0.90 has a little effect on the electrochemical performance of the battery. Very similar trends are also observed for higher J, e.g., $150 \mathrm{~A} / \mathrm{m}^{2}$. This observation implies that the $\mathrm{H}_{2}-\mathrm{H}_{2} \mathrm{O}$ diffusion resistance imposed by the reduction in $\varepsilon$ is negligible for the cases studied.

However, a combined effect from the reduction in $\varepsilon_{\mathrm{o}}$ and distance (d) between RSOFC and RCU would affect the chamber pressure (P) as will be discussed in the following section. Therefore, choosing a proper $\varepsilon_{\mathrm{o}}$ with a reasonable $\mathrm{d}$ is important to a normal operation of the battery.

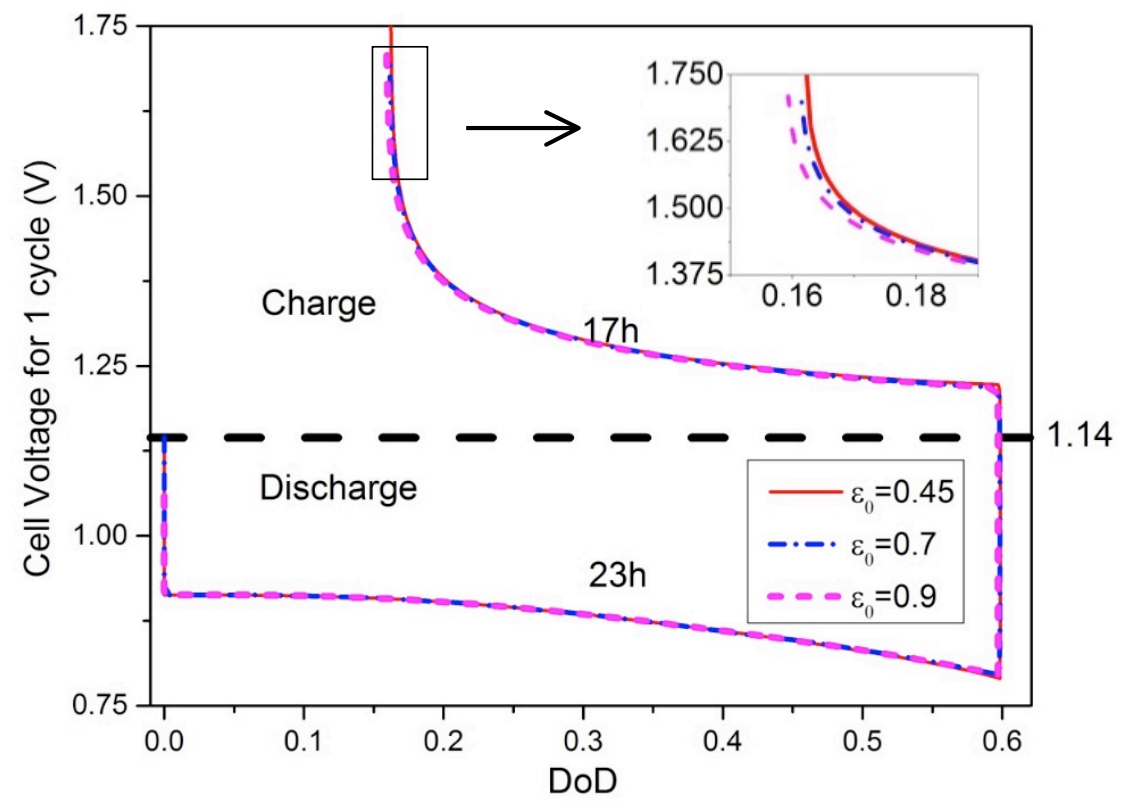

Fig.8 Profiles of cell voltage as a function of DoD during a discharge/charge cycle with different $\varepsilon_{\mathrm{o}}$ in RCU. $\left(\mathrm{J}=\mathrm{J}_{\mathrm{c}}=\mathrm{J}_{\mathrm{d}}=100 \mathrm{~A} / \mathrm{m}^{2}, \mathrm{~d}=1 \mathrm{~mm}\right)$

\subsection{The effect of distance (d) between RSOFC and RCU}


The d-value determines the size of the OSG chamber, thus the size of the battery stacks. A greater $d$ can hold more $\mathrm{H}_{2}-\mathrm{H}_{2} \mathrm{O}$, thus facilitating the electrochemical reactions occurring at RSOFC to reach equilibrium state faster between cycles. It can also serve as a buffer to the pressure variations incurred from volume change in RCU during cycling. However, too wide a distance would increase the mass transport resistance to $\mathrm{H}_{2}$ and $\mathrm{H}_{2} \mathrm{O}$ diffusion and result in a lager stack. On the other hand, too narrow a distance would increase P in OSG chamber, causing operational concerns. Therefore, investigation of the effect of $d$ on the battery's performance and chamber $P$ is necessary.

The profiles of cell voltage during a discharge/charge cycle are shown in Fig.9 as a function of DoD for different d values. It is evident that no significant difference in performance can be discerned for $\mathrm{d}=0.1,1$ and $10 \mathrm{~mm}$. Only a small effect is noticed for the charge cycle at $\mathrm{d}=10 \mathrm{~mm}$ (see the inset of Fig.9), which may imply that the diffusion of $\mathrm{H}_{2}$ and $\mathrm{H}_{2} \mathrm{O}$ starts to impact on the establishment of dynamic interaction between RSOFC and RCU.

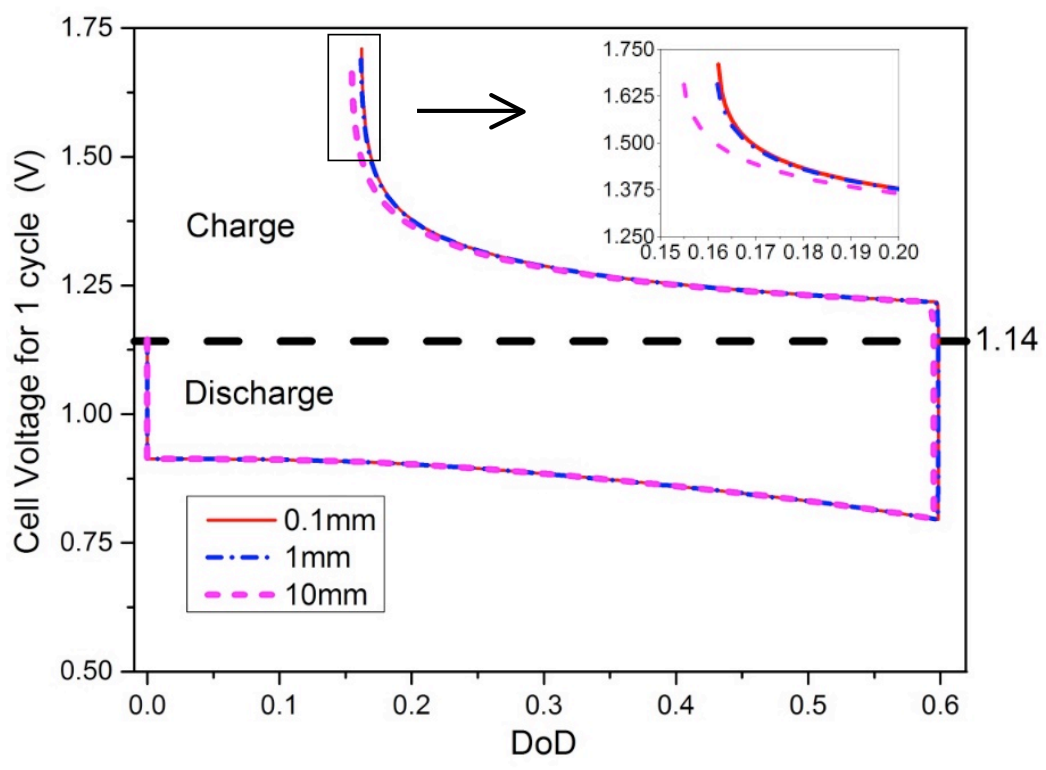


Fig. 9 Profiles of cell voltage as a function of DoD during a discharge/charge cycle with different distances between RSOFC and RCU. $\left(\mathrm{J}=\mathrm{J}_{\mathrm{c}}=\mathrm{J}_{\mathrm{d}}=100 \mathrm{~A} / \mathrm{m}^{2}, \varepsilon_{0}=0.7\right)$

While the distance may not play an important role in the electrochemical performance of the battery, it could have a significant impact on the pressure inside the OSG chamber due to a decreasing porosity in RCU during the discharge cycle.

Fig. 10 shows the variations of porosity with DoD under $\mathrm{J}=\mathrm{J}_{\mathrm{c}}=\mathrm{J}_{\mathrm{d}}=100 \mathrm{~A} / \mathrm{m}^{2}$. It is evident that the porosity in $\mathrm{RCU}$ decreases with $\mathrm{DoD}$, and the rate of porosity reduction also decreases with increasing $\varepsilon_{0}$. The reduced free volume in the OSG chamber can cause an increase in $\mathrm{P}$ as the oxygen is being continuously added into the chamber during the discharge cycle.

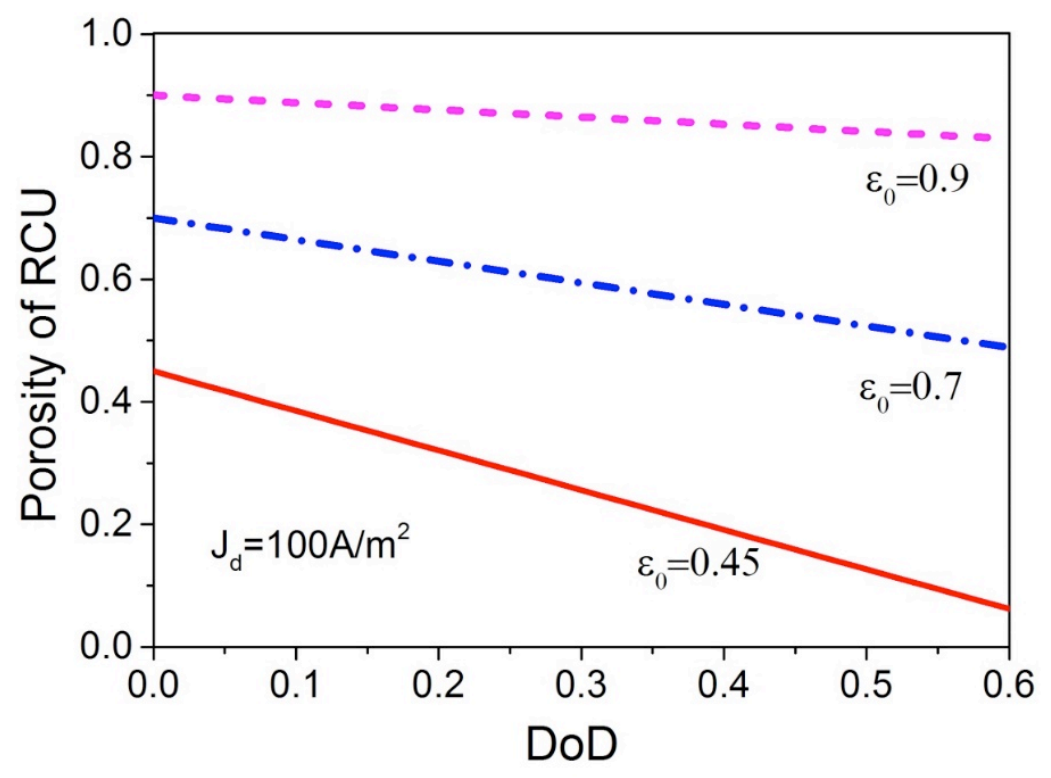

Fig.10 Porosity of RCU as a function of DoD at different initial porosities. 
Assuming $\mathrm{H}_{2}$ and $\mathrm{H}_{2} \mathrm{O}$ as ideal gases, the chamber $\mathrm{P}$ under $\mathrm{J}=\mathrm{J}_{\mathrm{c}}=\mathrm{J}_{\mathrm{d}}=100 \mathrm{~A} / \mathrm{m}^{2}$ and $\varepsilon_{\mathrm{o}}=0.45,0.70,0.90$ was estimated as a function of DoD; the results are shown in Fig. 11 . It is evident from the plot that for a wider distance such as $d \geq 1 \mathrm{~mm}$, the increase in chamber $\mathrm{P}$ is relatively small throughout the discharge cycle. However, as $\mathrm{d}$ decreases, $\mathrm{P}$ increases significantly. On the other hand, higher $\varepsilon_{\mathrm{o}}$ helps reduce the increase in $\mathrm{P}$, mitigating the effect of d. In general, too high a $\mathrm{P}$ may hinder the $\mathrm{O}^{2-}$ flux transporting from airelectrode to fuel-electrode by the RSOFC and possibly breach the integrity of the peripheral sealing of the battery. Therefore, optimizing the distance at which the performance and chamber pressure can be best balanced is necessary.
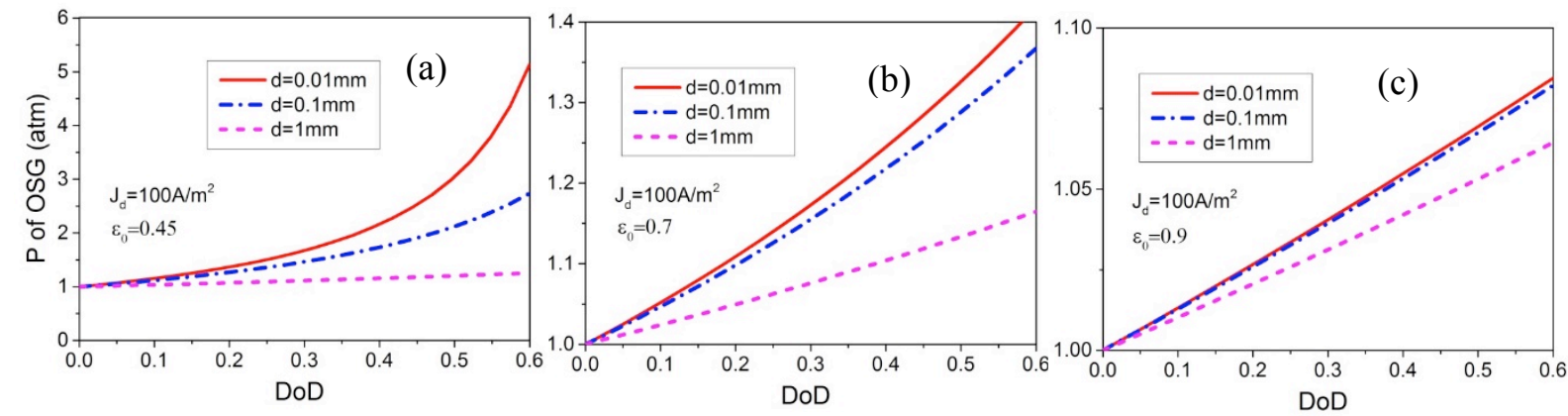

Fig.11 OSG-chamber pressure $\mathrm{P}$ (atm) as a function of DoD for different distances between RCU and RSOFC, (a) $\varepsilon_{0}=0.45$; (b) $\varepsilon_{0}=0.7$; (c) $\varepsilon_{0}=0.9$.

\subsection{The effect of kinetic rate of $\mathrm{Fe}_{3} \mathrm{O}_{4}$-reduction reaction}

As aforementioned, one of the root causes for the difficulty to recharge the battery is the sluggish kinetics of $\mathrm{Fe}_{3} \mathrm{O}_{4}$-reduction. Increasing the kinetic rate $\left(\mathrm{k}_{\mathrm{S}}\right.$, from Shrinking Core model) of $\mathrm{Fe}_{3} \mathrm{O}_{4}$ reduction is, therefore, necessary to improve the overall performance of the battery. From a materials perspective, the simplest way to increase the $\mathrm{k}_{\mathrm{S}}$ value is to 
increase the surface areas of the RCU materials. This assertion is supported by the Shrinking Core model ${ }^{18}$.

The effect of $\mathrm{k}_{\mathrm{S}}$ of $\mathrm{Fe}_{3} \mathrm{O}_{4}$-reduction reaction (here expressed as $\mathrm{k}_{\mathrm{S}} / \mathrm{k}_{\mathrm{S} \text {,exp }}$, where $\mathrm{k}_{\mathrm{S} \text {,exp }}$ is the baseline kinetic rate obtained from the experiment) on battery's performance is shown in Fig.12, where the profiles of cell voltage as a function of $\mathrm{DoD}$ during a discharge/charge cycle under $\mathrm{J}=\mathrm{J}_{\mathrm{c}}=\mathrm{J}_{\mathrm{d}}=100 \mathrm{~A} / \mathrm{m}^{2}$ are depicted for different $\mathrm{k}_{\mathrm{S}} / \mathrm{k}_{\mathrm{S} \text {,exp. It }}$ is illustrated that as $\mathrm{k}_{\mathrm{S}} / \mathrm{k}_{\mathrm{S} \text {,exp }}$ increases from 1 to 1.25 , the unconverted $\mathrm{Fe}_{3} \mathrm{O}_{4}$ decreases from $16 \%$ to $0.15 \%$, significantly improving the reversibility of the battery. A further increase in $\mathrm{k}_{\mathrm{S}} / \mathrm{k}_{\mathrm{S} \text {,exp }}$ can make the cell fully reversible, but the improvement of Round-Trip-Efficiency would be minimal as will be shown as follows. It is important to note that making the charge cycle fully reversible is critical to the cycle life of the battery since accumulation of unconverted $\mathrm{Fe}_{3} \mathrm{O}_{4}$ over the charge cycles could be the source of long-term degradation.

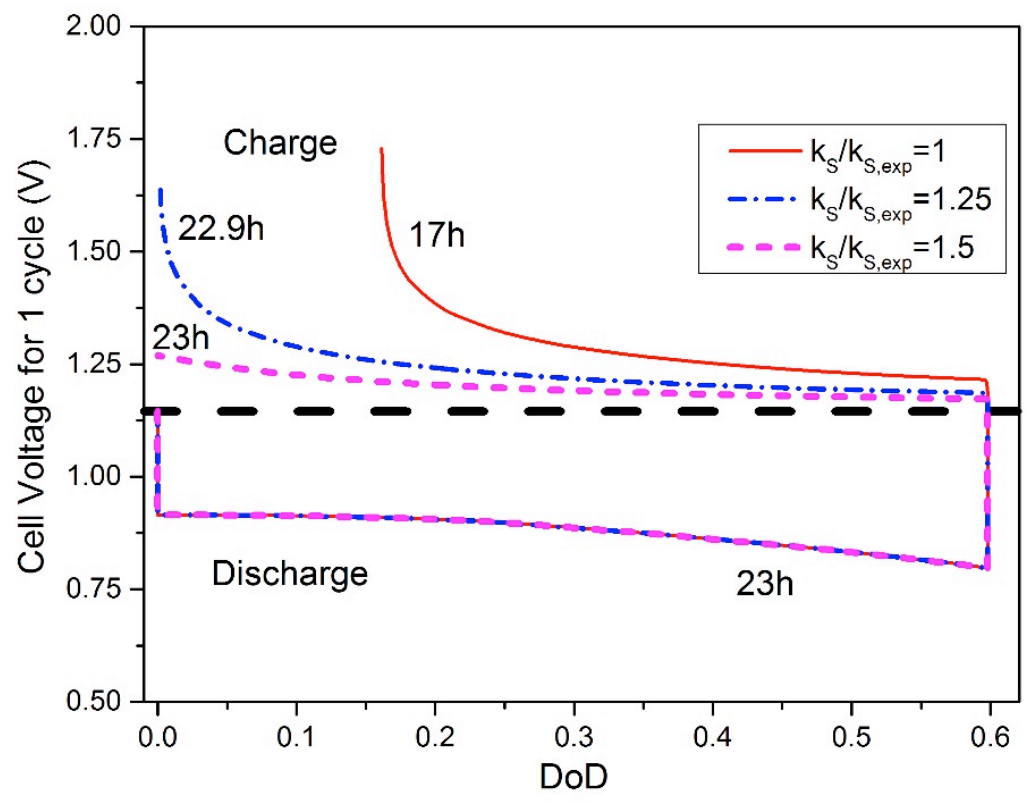

Fig.12 Profiles of cell voltage as a function of DoD during a discharge/charge cycle with different $\mathrm{k}_{\mathrm{S}} / \mathrm{k}_{\mathrm{S} \text {,exp. }}\left(\mathrm{J}=\mathrm{J}_{\mathrm{c}}=\mathrm{J}_{\mathrm{d}}=100 \mathrm{~A} / \mathrm{m}^{2}, \varepsilon_{0}=0.7, \mathrm{~d}=1 \mathrm{~mm}\right)$. 


\section{Performance optimization strategies}

Developing strategies to mitigate the slow $\mathrm{Fe}_{3} \mathrm{O}_{4}$-reduction kinetics is critically important to the success of SOIARB technology. As previously pointed out, the effects of $\mathrm{J}_{\mathfrak{c}}$, DoD and $\mathrm{k}_{\mathrm{S}} / \mathrm{k}_{\mathrm{S} \text {,exp }}$ on the performance of SOIARB are related. In the following, we focus on illustrating the combined effect of $\mathrm{J}_{\mathrm{c}}, \mathrm{DoD}$ and $\mathrm{k}_{\mathrm{S}} / \mathrm{k}_{\mathrm{S} \text {,exp }}$ on Specific Energy (SE) and Round-Trip Efficiency (RTE) of the battery. To concentrate on the performance-limiting charge cycle, $\mathrm{J}_{\mathrm{d}}$ is kept as $100 \mathrm{~A} / \mathrm{m}^{2}$ for the discussion and the maximum DoD is chosen as 0.6 .

The combined effects of $\mathrm{J}_{\mathrm{c}}$, DoD and $\mathrm{k}_{\mathrm{S}} / \mathrm{k}_{\mathrm{S} \text {,exp }}$ on SE and RTE are shown in 3D surface plots of Figs.13-15. The $\mathrm{J}_{\mathrm{c}}$ is purposely selected to be lower than, equal to and higher than $\mathrm{J}_{\mathrm{d}}=100 \mathrm{~A} / \mathrm{m}^{2}$. For $\mathrm{J}_{\mathrm{c}}=60 \mathrm{~A} / \mathrm{m}^{2}$, Fig. 13 a shows that the charge $\mathrm{SE}$ (or $\mathrm{SE}_{\mathrm{c}}$ ) increases with DoD but decreases with $\mathrm{k}_{\mathrm{S}} / \mathrm{k}_{\mathrm{S} \text {,exp }}$, which are well expected. Clearly, the minimum $\mathrm{SE}_{\mathrm{C}}=1385 \mathrm{Wh} / \mathrm{kg}-\mathrm{Fe}$ is found at $\mathrm{DoD}=0.1$ and $\mathrm{k}_{\mathrm{S}} / \mathrm{k}_{\mathrm{S}, \exp }=4$, the most favorable condition for a reversible charge cycle. The corresponding RTE is plotted in Fig.13b, showing an opposite trend to $\mathrm{SE}_{\mathrm{c}}$ in Fig. $13 \mathrm{a}$. The maximum $\mathrm{RTE}=0.85$ is observed at $\mathrm{DoD}=0.1$ and $\mathrm{k}_{\mathrm{S}} / \mathrm{k}_{\mathrm{S} \text { exp }}=4$.
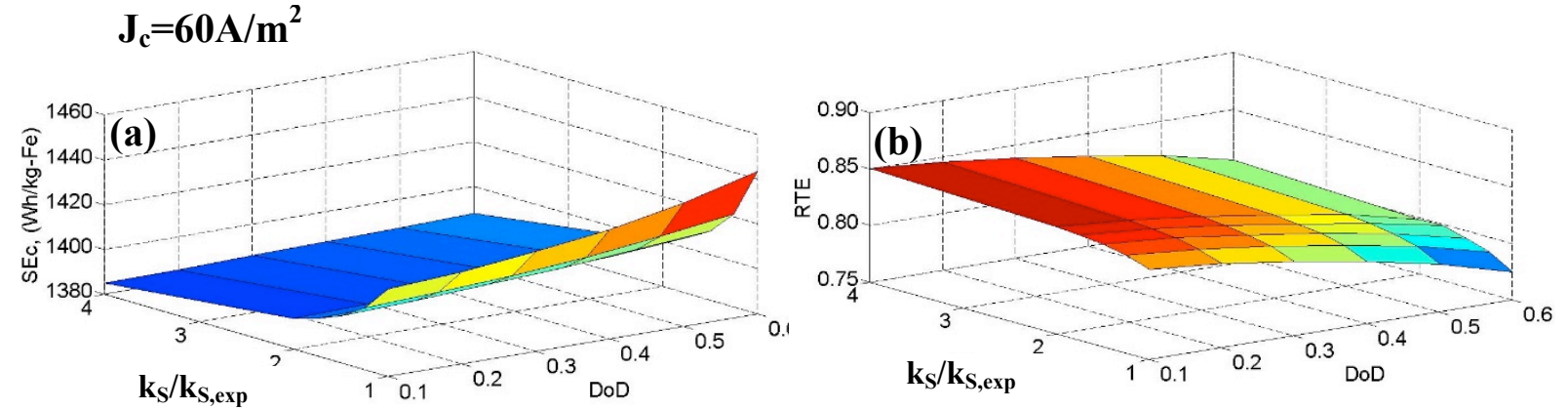

Fig.13 $\mathrm{SE}_{\mathrm{c}}(\mathrm{Wh} / \mathrm{kg}-\mathrm{Fe})$ and RTE as a function of DoD and $\mathrm{k}_{\mathrm{S}} / \mathrm{k}_{\mathrm{S} \text {,exp }}$ with $\mathrm{J}_{\mathrm{c}}=60 \mathrm{~A} / \mathrm{m}^{2}$. 
For the case of $J_{c}=J_{d}=100 A / m^{2}$, the $3 D$ surface plots are shown in Fig. $14 a$ and $b$; they follow the same trend as Fig.13a and b, but with higher $\mathrm{SE}_{\mathrm{c}}$ and lower RTE, indicating a decrease in reversibility at higher $\mathrm{J}_{\mathrm{c}}$. In fact, there is $16 \%$ unconverted $\mathrm{Fe}_{3} \mathrm{O}_{4}$ at the end of the charge cycle when $\mathrm{DoD}=0.6$ and $\mathrm{k}_{\mathrm{S}} / \mathrm{k}_{\mathrm{S} \text {,exp }}=1$. The best performance is obtained for $\mathrm{DoD}=0.1$ and $\mathrm{k}_{\mathrm{S}} / \mathrm{k}_{\mathrm{S}, \exp }=4$ at which the battery is fully reversible with $\mathrm{SE}_{\mathrm{c}}=1472 \mathrm{Wh} / \mathrm{kg}-\mathrm{Fe}$ and $\mathrm{RTE}=0.80$.
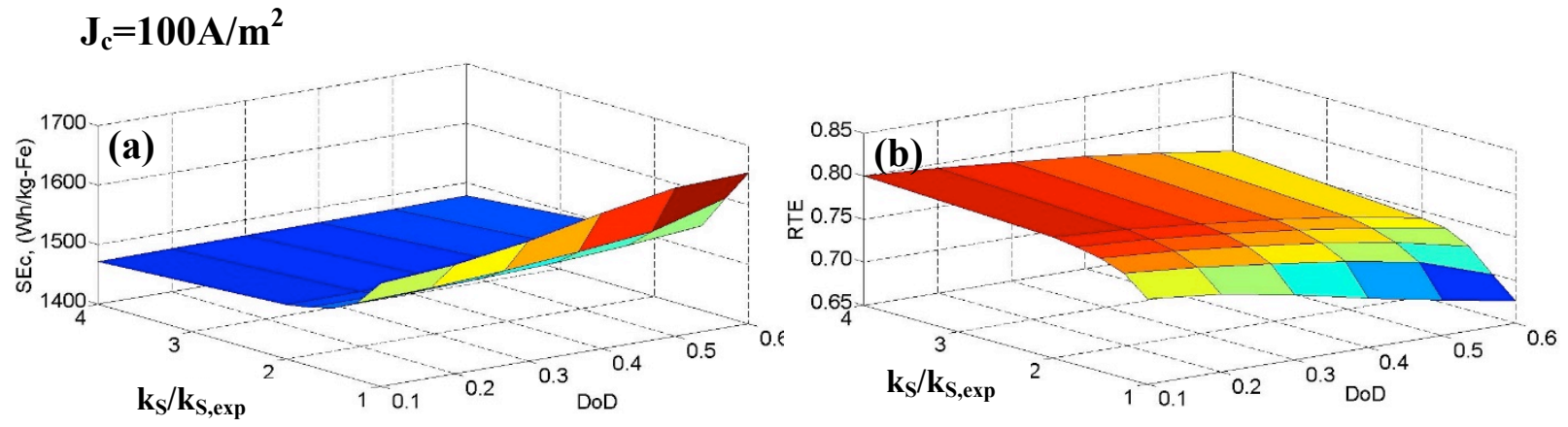

Fig.14 $\mathrm{SE}_{\mathrm{c}}(\mathrm{Wh} / \mathrm{kg}-\mathrm{Fe})$ and RTE as a function of DoD and $\mathrm{k}_{\mathrm{S}} / \mathrm{k}_{\mathrm{S} \text {,exp }}$ with $\mathrm{J}_{\mathrm{c}}=100 \mathrm{~A} / \mathrm{m}^{2}$.

For the case of $\mathrm{J}_{\mathrm{c}}=140 \mathrm{~A} / \mathrm{m}^{2}$, the variations of $\mathrm{SE}_{\mathrm{c}}$ and RTE with DoD and $\mathrm{k}_{\mathrm{S}} / \mathrm{k}_{\mathrm{S} \text {,exp }}$ remain the same as the previous cases, see the $3 \mathrm{D}$ surface plots in Fig. 15a and b. It is worth mentioning that $\mathrm{SE}_{\mathrm{c}}$ and $\mathrm{RTE}$ become much more sensitive to the change of $\mathrm{k}_{\mathrm{S}} / \mathrm{k}_{\mathrm{S} \text {,exp }}$ at higher DoD. In other words, insufficiently high $\mathrm{k}_{\mathrm{S}} / \mathrm{k}_{\mathrm{S}, \exp }$ could result in a sharp decrease in RTE if DoD is operated high. 

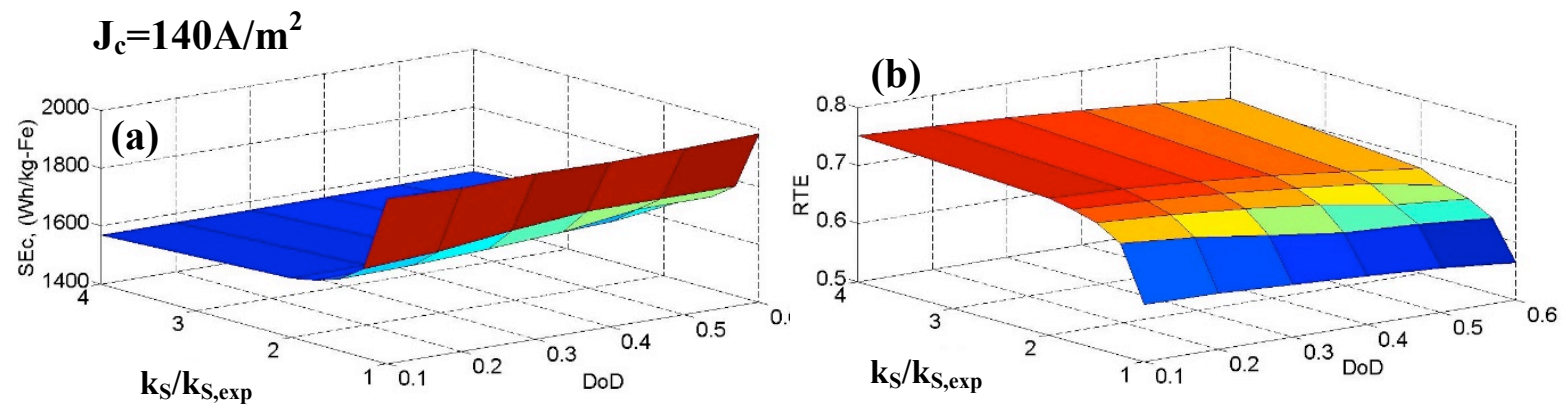

Fig.15 $\mathrm{SE}_{\mathrm{c}}(\mathrm{Wh} / \mathrm{kg}-\mathrm{Fe})$ and RTE as a function of DoD and $\mathrm{k}_{\mathrm{S}} / \mathrm{k}_{\mathrm{S} \text {,exp }}$ with $\mathrm{J}_{\mathrm{c}}=140 \mathrm{~A} / \mathrm{m}^{2}$.

To facilitate the understanding of the 3D surface plots shown above, Fig.16 of a 2D plot is further plotted to display the $\mathrm{SE}_{\mathrm{c}}$ and $\mathrm{RTE}$ as a function of $\mathrm{J}_{\mathrm{c}}$ at four extreme conditions: $\mathrm{DoD}=0.1$ and $0.6 ; \mathrm{k}_{\mathrm{S}} / \mathrm{k}_{\mathrm{S} \text {,exp }}=1$ and 4 . From Fig. $16 \mathrm{a}$, the trend is clear: if $\mathrm{k}_{\mathrm{S}}$ is sufficiently high the DoD will have a little effect on $\mathrm{SE}_{\mathrm{c}}$ over the entire $\mathrm{J}_{\mathrm{c}}$ range. For RTE shown in Fig. 16b, the trend is slightly different. The advantage of having higher $\mathrm{k}_{\mathrm{S}} / \mathrm{k}_{\mathrm{S} \text {,exp }}$ is only manifested at higher $\mathrm{J}_{\mathrm{c}}$. At lower $\mathrm{J}_{\mathrm{c}}$, the RTE seems to be more impacted by DoD. Having said this, the general trend is still true in that lower DoD and higher $\mathrm{k}_{\mathrm{S}} / \mathrm{k}_{\mathrm{S}, \exp }$ would favor a higher RTE for the entire $\mathrm{J}_{\mathrm{c}}$ range.
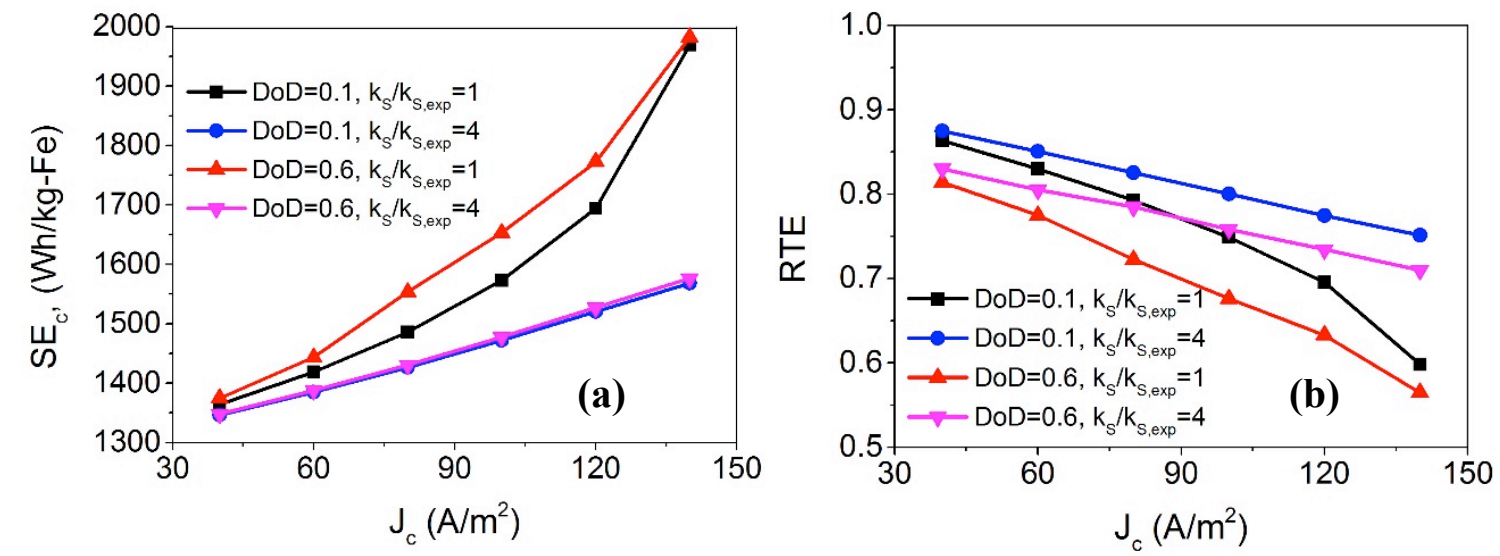

Fig.16 (a) $\mathrm{SE}_{\mathrm{c}},(\mathrm{Wh} / \mathrm{kg}-\mathrm{Fe})$; (b) RTE as a function of $\mathrm{J}_{\mathrm{c}}$ for selected cases. 
In conclusion, at low $\mathrm{J}_{\mathrm{c}}$ when the reduction kinetics of $\mathrm{Fe}_{3} \mathrm{O}_{4}$ are not yet performancelimiting, it is more effective to achieve a high RTE by decreasing DoD. To achieve a required energy capacity, a longer charge time is, therefore, needed. At high $\mathrm{J}_{\mathrm{c}}$ when the reduction kinetics of $\mathrm{Fe} 3 \mathrm{O} 4$ becomes performance-limiting, a sufficiently high $\mathrm{k}_{\mathrm{S}} / \mathrm{k}_{\mathrm{S} \text {,exp }}$ is needed to obtain a higher RTE as the effect of DoD becomes less significant.

\section{Conclusions}

In the present work, the effects of discharge and charge current densities, depth-ofdischarge, initial porosity of RCU, distance between RSOFC and RCU, and kinetic rate constant of $\mathrm{Fe}_{3} \mathrm{O}_{4}$-reduction reaction on electrochemical performance of SOIARB have been systematically investigated using a high-fidelity $2 \mathrm{D}$ axial symmetric multiphysics model. The results explicitly show that the charge process of $\mathrm{Fe}_{3} \mathrm{O}_{4}$-reduction is the performance-limiting step. The initial porosity of RCU and distance between RSOFC and RCU have an insignificant effect on the performance, implying that the $\mathrm{H}_{2}-\mathrm{H}_{2} \mathrm{O}$ diffusion through the chamber and inside RCU bed is not a limiting factor. However, the chamber pressure could be substantially increased if the initial porosity and distance are too small, prompting the need for optimizing these two parameters in engineering design. Finally, charge current density, depth-of-discharge and kinetic rate are shown to have the most significant effect on the specific energy and round-trip-efficiency of the battery. A careful combination of these parameters can lead to a balanced energy capacity and cycle efficiency for the best performance. 


\section{Acknowledgements}

The work is funded by the Advanced Research Projects Agency-Energy (ARPA-E), U.S.

Department of Energy, under Award number DE-AR0000492. The authors would also like to acknowledge the support from a grant (Project Number: PolyU 152127/14E) from Research Grant Council, University Grants Committee, Hong Kong SAR.

\section{References}

1. N. S. Xu, X. Li, X. Zhao, J. B. Goodenough and K. Huang, Energ Environ Sci, 4, 4942 (2011).

2. A. Leonide, W. Drenckhahn, H. Greiner and H. Landes, J Electrochem Soc, 161, A1297 (2014).

3. H. T. Wang, J. T. Chen, C. H. Luo and R. Qiao, Solid State Ionics, 263, 71 (2014).

4. X. Zhao, Y. H. Gong, X. Li, N. S. Xu and K. Huang, J Mater Chem A, 1, 14858 (2013).

5. X. Zhao, X. Li, Y. H. Gong, N. S. Xu, K. Romito and K. Huang, Chemical Communications, 49, 5357 (2013).

6. X. Zhao, N. S. Xu, X. Li, Y. H. Gong and K. Huang, Rsc Adv, 2, 10163 (2012).

7. A. Inoishi, S. Ida, S. Uratani, T. Okano and T. Ishihara, Rsc Adv, 3, 3024 (2013).

8. A. Inoishi, Y. W. Ju, S. Ida and T. Ishihara, Chemical Communications, 49, 4691 (2013).

9. A. Inoishi, T. Sakai, Y. W. Ju, S. Ida and T. Ishihara, J Mater Chem A, 1, 15212 (2013).

10. X. Zhao, Y. H. Gong, X. Li, N. S. Xu and K. Huang, J Electrochem Soc, 160, A1241 (2013).

11. X. Zhao, Y. H. Gong, X. Li, N. S. Xu and K. Huang, J Electrochem Soc, 160, A1716 (2013).

12. X. Zhao, X. Li, Y. Gong and K. Huang, Chemical Communications, 623 (2014).

13. A. Inoishi, Y. W. Ju, S. Ida and T. Ishihara, J Power Sources, 229, 12 (2013).

14. A. Inoishi, Y. Okamoto, Y. W. Ju, S. Ida and T. Ishihara, Rsc Adv, 3, 8820 (2013).

15. A. Inoishi, T. Sakai, Y. W. Ju, S. Ida and T. Ishihara, J Power Sources, 262, 310 (2014).

16. H. Ohmori, S. Uratani and H. Iwai, J Power Sources, 208, 383 (2012).

17. M. Guo, X. Zhao, R. E. White and K. Huang, J Electrochem Soc, 160, A2085 (2013). 
18. X. Jin, X. Zhao and K. Huang, J Power Sources, 280, 195 (2015).

19. X. Jin, A. M. Uddin, X. Zhao, R. White and K. Huang, J Electrochem Soc, 162, A1476 (2015).

20. X. Zhao, A New Class of Solid Oxide Metal-Air Redox Batteries for Advanced Stationary Energy Storage, in Mechanical Engineering, University of South Carolina (2013).

21. Y. Y. Xie, H. P. Ding and X. J. Xue, J Power Sources, 241, 718 (2013).

22. Y. Y. Xie and X. J. Xue, J Power Sources, 209, 81 (2012).

23. Y. Y. Xie and X. J. Xue, Solid State Ionics, 224, 64 (2012).

24. J. C. Maya and F. Chejne, Energy \& Fuels, 28, 5434 (2014).

25. M. E. Davis and R. J. Davis, Fundamentals of Chemical Reaction Engineering, McGraw-Hill Higher Education, New York (2003).

26. S. Noorman, F. Gallucci, M. V. Annaland and J. A. M. Kuipers, Chem Eng J, 167, 297 (2011).

27. J. A. Pena, E. Lorente, E. Romero and J. Herguido, Catal Today, 116, 439 (2006).

28. E. Lorente, J. A. Pena and J. Herguido, Int J Hydrogen Energ, 33, 615 (2008).

29. E. R. Fotsing, Phase Transformation Kinetics and Microstructure of Carbide and Diboride Based Ceramics, in, p. 141, Fakultät für Bergbau, Hüttenwesen und Maschinenwesen of the Technische Universität Clausthal (2005).

\section{Nomenclature}

$\begin{array}{ll}\mathrm{A},\left(\mathrm{m}^{2}\right) & \text { Cross area } \\ \mathrm{c},\left(\mathrm{mol} \cdot \mathrm{m}^{-3}\right) & \text { Molar concentration } \\ d_{\text {nore }},(\mathrm{m}) & \text { Diameter of spherical particle of the porous medium } \\ \mathrm{d}_{\mathrm{p}},(\mathrm{m}) & \text { Pore diameter of the porous medium } \\ \mathrm{D}_{\mathrm{ij}},\left(\mathrm{m}^{2} \cdot \mathrm{s}^{-1}\right) & \text { Binary diffusion coefficient for a pair of species i and } \mathrm{j} \\ \mathrm{D}_{\mathrm{kn}}, \mathrm{i},\left(\mathrm{m}^{2} \cdot \mathrm{s}^{-1}\right) & \text { Knudsen diffusion coefficient of species } \mathrm{i} \\ \mathrm{E},(\mathrm{V}) & \text { Nernst potential } \\ \mathrm{F},\left(\mathrm{C} \cdot \mathrm{mol}^{-1}\right) & \text { Faraday's constant, } 96485 \\ \mathrm{G},\left(\mathrm{J} \cdot \mathrm{mol}^{-1}\right) & \text { Gibbs free energy } \\ \mathrm{J},\left(\mathrm{A} \cdot \mathrm{m}^{-2}\right) & \text { Operating current density } \\ \mathrm{K} & \text { Equilibrium constant } \\ \mathrm{k}_{\mathrm{D}},\left(\mathrm{m}^{2} \cdot \mathrm{s}^{-1}\right) & \text { Reference diffusivity } \\ k_{o},\left(\mathrm{~s}^{-1}\right) & \text { Global oxidation rate constant } \\ k_{f . I},\left(\mathrm{~s}^{-1}\right) & \text { Forward reaction constant in JMAK model } \\ k_{h . I},\left(\mathrm{~s}^{-1}\right) & \text { Backward reaction constant in JMAK model } \\ k_{f . S},\left(\mathrm{~m} \cdot \mathrm{s}^{-1}\right) & \text { Forward reaction constant in Shrinking-Core model } \\ k_{h . S},\left(\mathrm{~m} \cdot \mathrm{s}^{-1}\right) & \text { Backward reaction constant in Shrinking-Core model } \\ k_{S},\left(\mathrm{~m} \cdot \mathrm{s}^{-1}\right) & \text { Reaction constant in Shrinking-Core model } \\ \mathrm{M}_{\mathrm{i}},\left(\mathrm{kg} \cdot \mathrm{mol}^{-1}\right) & \text { Molar weight of species i } \\ \mathrm{M},\left(\mathrm{kg} \cdot \mathrm{mol}^{-1}\right) & \text { Mean molar weight of gas mixture } \\ m_{F e . n},(\mathrm{~kg}) & \text { Initial load of Fe } \\ N_{i},\left(\mathrm{~kg} \cdot \mathrm{m}^{-2} \cdot \mathrm{s}^{-1}\right) & \text { Flux vector of species i } \\ & \end{array}$


$\mathrm{N}$

$\mathrm{n},(\mathrm{mol})$

$\mathrm{i}_{\text {ict }},\left(\mathrm{A} \cdot \mathrm{m}^{-2}\right)$

$\mathrm{p},(\mathrm{Pa})$

$\mathrm{R},\left(\mathrm{J} \cdot\left(\mathrm{mol}^{-1} \cdot \mathrm{K}^{-1}\right)\right)$

$\mathrm{R}_{\mathrm{c} 0},(\mathrm{~m})$

$\mathrm{r},\left(\mathrm{mol} \cdot \mathrm{m}^{-3} \cdot \mathrm{s}^{-1}\right)$

$r_{c},(\mathrm{~m})$

$\mathrm{R}_{\mathrm{i}},\left(\mathrm{kg} \cdot \mathrm{m}^{-3} \cdot \mathrm{s}^{-1}\right)$

$\mathrm{S}_{\mathrm{i}}$

$\mathrm{Sa},\left(\mathrm{m}^{-1}\right)$

$\mathrm{T},(\mathrm{K})$

$\mathrm{t},(\mathrm{s})$

$\mathrm{V},(\mathrm{V})$

$\mathrm{x}_{\mathrm{j}}$

\section{Greek symbols}

$\sigma,\left(\mathrm{S} \cdot \mathrm{m}^{-1}\right)$

$\phi,(\mathrm{V})$

$\eta,(\mathrm{V})$

$\rho,\left(\mathrm{kg} \cdot \mathrm{m}^{-3}\right)$

$\omega_{\mathrm{i}}, \omega_{\mathrm{j}}$

$\mathrm{V}_{\mathrm{i}}$

$\varepsilon$

$\tau$

\section{Subscripts}

c

d

e

eff

el

eq

i

g

o

h

react

Prod

$\mathrm{S}$

Superscripts

0
Avrami exponent

Number of electrons

Local charge transfer current density

Pressure

Gas constant, 8.314

Initial radius of $\mathrm{Fe}_{3} \mathrm{O}_{4}$ core

Reaction rate

Radius of the core in the shrinking core model

Reaction source term for species $i$

Stoichiometric coefficient of species $i$

Electrochemical reaction active area per unit volume

Temperature

Time

Cell voltage

Molar fraction of species $\mathrm{j}$

Conductivity

Potential

Overpotential

Density

Mass fraction of species $\mathrm{i}, \mathrm{j}$

Kinetic volume of species $i$

Porosity

Tortuosity

Charge

Discharge

Electronic

Effective

Electrolyte

Equilibrium

Ionic

Gas

Oxygen electrode

Hydrogen electrode

Reactant

Product

Shrinking core

Ideal/Initial 
Meaning of Abbreviations

$\begin{array}{ll}\text { DoD } & \text { Depth of Discharge } \\ \text { FEM } & \text { Finite Element Method } \\ \text { Oxygen shuttle gas } \\ \text { RTE } & \text { round-trip efficiency } \\ \text { RSOFC } & \text { reversible Solid Oxide Fuel Cell } \\ \text { RCU } & \text { Redox Cycle Unit } \\ \text { SOIARB } & \text { Solid Oxide Iron-Air Redox Battery } \\ \text { SE } & \text { Specific Energy }\end{array}$

